\title{
Penerapan Permainan Scrabble Untuk Meningkatkan Penguasaan Kosakata Anak
}

\author{
Mohamad Muspawi, Irma Suryani, Arni Yolanda Rahayu \\ Universitas Jambi, Jambi, Indonesia \\ Email corresponding author: muspawi01@gmail.com
}

\begin{abstract}
ABSTRAK
Hal yang melatar belakangi penelitian ini adalah banyaknya anak usia 5-6 tahun di kelas B3 TK Dharma Wanita Mendalo Darat yang penguasaan kosakatanya belum mencapai indikator keberhasilan sesuai tahapan usianya. Berdasarkan hasil observasi awal, diperlukan adanya penelitian tindakan kelas yang bertujuan untuk meningkatkan penguasaan kosakata anak melalui permainan scrabble. Permainan scrabble dimainkan dengan aturan yang telah ditetapkan dan telah dimodifikasi sesuai dengan tema. Kemudian anak diperdengarkan rekaman suara sesuai tema dan anak ikut bernyanyi dengan tujuan anak dapat mengingat kata yang akan disusunnya. Setelah permainan selesai, dilanjutkan dengan tanya jawab antara anak dan guru tentang materi yang telah dimainkan oleh anak. Penelitian ini menggunakan jenis penelitian tindakan kelas. Menurut Daryanto (2014) bahwa PTK merupakan penelitian yang dilakukan oleh guru di dalam kelas dan melalui refleksi diri yang bertujuan untuk memperbaiki kualitas pembelajaran di kelas, sehingga hasil belajar anak dapat ditingkatkan. Teknik pengumpulan data menggunakan dokumentasi dan lembar observasi. Penguasaan kosakata anak sebelum adanya tindakan masih belum berkembang dengan baik dengan nilai $25,23 \%$ dalam kategori sangat tidak setuju. Setelah dilakukan penelitian pada siklus I dengan menggunakan permainan scrabble mengalami peningkatan pada pertemuan IV menjadi $72,19 \%$. Penguasaan kosakata anak telah mengalami peningkatan namun belum mencapai ketuntasan yang telah ditetapkan sehingga dilanjutkan siklus II. Siklus II menggunakan media pendukung berupa iringan musik rekaman suara sesuai dengan kata pada scrabble dan pemberian reward hingga pertemuan IV dan mengalami peningkatan sebesar $88,57 \%$ dan telah melampaui batas ketuntasan yaitu $80 \%$, oleh karena itu penelitian dihentikan pada siklus II. Berdasarkan hasil data yang didapatkan, dapat disimpulkan bahwa penguasaan kosakata anak usia 5-6 tahun di TK Dharma Wanita Mendalo Darat dapat ditingkatkan melalui permainan scrabble dengan penggunaan media pendukung berupa iringan musik rekaman suara sesuai dengan kata pada scrabble dan pemberian reward.
\end{abstract}

Kata Kunci: Penguasaan Kosakata, Permainan Scrabble

\section{PENDAHULUAN}

Sosok anak usia dini adalah individu yang pada prosesnya mengalami suatu perkembangan dengan pesat dan fundamental bagi kehidupan selanjutnya. Anak usia dini pada masa ini juga sering disebut masa golden ages, karena perkembangannya mengalami peningkatan yang signifikan. Perkembangan yang dialami oleh anak perlu adanya stimulus yang diberikan oleh orang yang ada di sekitarnya. Ada banyak cara yang dapat dilakukan untuk mengembangkan setiap aspek perkembangan anak yaitu melalui pendidikan anak usia dini, baik melalui keluarga maupun lembaga pendidikan.

Black et al., dalam Sofyan dkk (2019) berpendapat bahwa pendidikan anak usia dini bertujuan untuk membentuk pertumbuhan dan perkembangan anak secara optimal sehingga memiliki kesiapan untuk memasuki pendidikan lebih lanjut. Hal ini sesuai dengan UndangUndang Nomor 20 Tahun 2003 dalam Sujiono (2013) tentang Sistem Pendidikan Nasional berkaitan dengan Pendidikan Anak Usia Dini tertulis pada pasal 1 ayat 14 ditegaskan bahwa Pendidikan Anak Usia Dini adalah upaya pembinaan yang diberikan kepada anak sejak lahir sampai usia enam tahun melalui pemberian rangsangan pendidikan untuk membantu pertumbuhan jasmani dan rohani, agar anak memiliki kesiapan dalam memasuki pendidikan selanjutnya.

Dilihat dari pengertian di atas menunjukkan bahwa pendidikan anak usia dini memegang peran yang sangat penting dalam menentukan perkembangan anak selanjutnya. Hal ini 
dikarenakan pendidikan anak usia dini merupakan pondasi dasar bagi kepribadian anak. Pendidikan yang ada pada saat ini beragam jenisnya, ada pendidikan formal, informal, dan non formal. Pendidikan yang diberikan kepada anak sejak dini disesuaikan dengan kemampuan yang dimiliki anak untuk mengembangkan setiap aspek perkembangan yang ada dalam diri anak. Kegiatan yang diberikan kepada anak usia dini berupa kegiatan bermain sambil belajar agar memberikan perasaan menyenangkan dalam diri anak.

Bermain sambil belajar pada anak usia dini bertujuan untuk mengembangkan seluruh aspek perkembangan yang ada dalam diri anak. Salah satu aspek perkembangan yang dapat dikembangan melalui kegiatan bermain yaitu perkembangan bahasa pada anak. Menurut Sofyan (2015) mengungkapkan bahwa bahasa adalah aspek perkembangan yang berperan penting dalam kehidupan manusia. Komponen berbahasa salah satunya adalah berbicara yang merupakan alat komunikasi pada manusia.

Menurut Lovit dalam Sofyan (2015) perkembangan bahasa dapat dibagi ke dalam tiga bentuk perkembangan yaitu perkembangan kosakata, perkembangan semantik dan sintaktik, serta perkembangan variasi dan kompleksitas berbahasa. Pada perkembangan bahasa anak, ada berbagai aspek yang perlu dikembangkan salah satunya penguasaan kosakata pada anak sebagai persiapan dalam menghadapi jenjang pendidikan yang lebih tinggi. Menurut KBBI dalam Alawiyah,dkk (2018) menyatakan bahwa kosakata adalah sekumpulan perbendaharaan kata yang dapat dikuasai oleh seseorang untuk membentuk sebuah kalimat.

Penguasaan kosakata dapat mempengaruhi kemampuan individu dalam keterampilan berbahasanya seperti, menyimak, mendengar, membaca serta menulis. Kosakata dari suatu bahasa itu selalu mengalami perubahan dan berkembang karena kehidupan yang semakin kompleks. Oleh karena itu, pentingnya pembelajaran kosakata sejak dini yang diajarkan secara teratur dan terarah agar kemampuan tersebut dimiliki oleh setiap anak dalam menjalani setiap kehidupannya. Meningkatkan penguasaan kosakata anak, dapat dilakukan melalui stimulus yang diberikan dengan kegiatan bermain sambil belajar.

Kegiatan bermain sambil belajar, merupakan suatu hal yang diutamakan dalam proses pembelajaran anak usia dini. Penggunaan alat permainan edukatif (APE) akan mampu mengembangkan berbagai aspek perkembangan anak. Akan tetapi, di lapangan masih banyak ditemukan anak yang penguasaan kosakatanya rendah sehingga perlu distimulus dengan baik melalui pemanfaatan APE dan media lain yang mendukung.

Sehubungan dengan permasalahan di atas, penulis bermaskud memberikan solusi alternatif untuk anak dalam meningkatkan penguasaan kosakata yaitu dengan penggunaan permainan scrabble yang dimodifikasi agar mampu meningkatkan penguasaan kosakata anak melalui menyusun huruf-huruf di papan scrabble yang membentuk sebuah kata yang dapat dipahami anak. Melalui penggunaan media permainan mempermudah anak dalam bermain dan mengembangkan berbagai aspek perkembangan yang ada dalam dirinya. Oleh karena itu, penulis tertarik untuk meningkatkan penguasaan kosakata anak usia 5-6 tahun melalui permainan scrabble. Selain itu penulis berharap agar permainan ini dapat bermanfaat dan berpengaruh terhadap berbagai aspek perkembangan lainnya pada diri anak.

\section{TINJAUAN PUSTAKA}

\subsection{Penguasaan Kosakata}

Kosakata atau pembendaharaan kata merupakan jumlah seluruh kata-kata dalam suatu bahasa yang tersusun seperti kamus sesuai abjad serta digunakan untuk berbicara, menulis dan membaca secara lisan maupun tulisan yang akan selalu mengalami perubahan dan berkembang semakin kompleks. Menurut Syamsudin dalam Yusuf (2012) pada masa awal, anak-anak sudah mampu menguasai kosakata sekitar 2.500 kata dan pada masa anak-anak akhir sekitar usia 11-12 tahun 
telah menguasai sebanyak 5.000 kata. Penguasaan kosakata yang dimiliki oleh anak beragam sesuai dengan kemampuan dan stimulus yang diberikan kepada anak. Penguasaan kosakata terbagi menjadi dua jenis yaitu penguasaan kosakata aktif produktif dan pasif resptif.

Kosakata yang dapat dipahami oleh anak meliputi kata-kata yang sering didengar anak diantaranya kata benda, kata kerja, kata sifat serta kata tugas yang sering dilakukan anak dalam kehidupan sehari-hari. Menurut Tarigan (2015) ada dua cara anak memahami kosakata yaitu melalui (1) mendengar kata-kata dari orang tua, anak yang lebih tua, teman sepermainan, televisi, radio, pusat perbelanjaan dan tempat umum lainnya yang pernah dikunjungi oleh anak, (2) mengalaminya sendiri dengan cara mengatakannya, memakannya, meminumnya, merabanya serta mencium benda yang ada di sekitarnya untuk mengetahui jenis benda.

Melalui cara anak mendapatkan kosakata, ada tolak ukur dari kemampuan penguasaan kosakata yang disebut indikator keberhasilan. Menurut Djiwandono (2011) masing-masing kategori penguasaan kosakata adalah Penguasaan pasif-reseptif dan aktif-produktif terhadap penguasaan kosakata yang ditunjukkan dalam bentuk kemampuan yang meliputi: (1) Menunjukkan benda-benda atau memperagakan sikap, tingkah laku yang dimaksud oleh kata kata tertentu (2) Memilih kata sesuai dengan makna yang diberikan sesuai dengan jumlah kata yang disediakan (3) Memilih kata yang memiliki arti yang sama atau mirip (sinonim) (4) Memilih kata yang memiliki arti yang berlawanan (antonim) (5) Menyebutkan kata sesuai dengan makna yang diminta (5) Menyebutkan kata lain yang memiliki arti sama atau mirip (sinonim) (6) Menyebutkan kata lain yang berlawanan (antonim) (7) Menyebutkan kata lain yang berlawanan (antonim).

\subsection{Permainan Scrabble}

Permainan scrabble merupakan permainan menyusun kepingan huruf-huruf alfabet menjadi sebuah kata di atas sebuah papan berbentuk persegi yang dapat disusun secara mendatar atau menurun seperti teka-teki silang dan dapat dimainkan oleh 2 atau 4 orang anak. Permainan ini bertujuan membina penguasaan kosakata, melatih ejaan, dan melatih penguasaan struktur morfologis pada anak. Permainan scrabble beragam jenisnya dan pada umumnya digunakan untuk anak sekolah menengah pertama dan sekolah menengah atas. Namun belakangan ini permainan scrabble sudah mulai bisa digunakan untuk anak usia dini hingga anak berkebutuhan khusus. Akan tetapi scrabble yang digunakan bentuknya akan berbeda dengan scrabble untuk anak-anak usia sekolah menengah.

Salah satunya untuk scrabble pada anak usia dini dapat menggunakan scrabble junior yang dimodifikasi untuk bisa digunakan oleh anak usia dini di luar negeri. Hal tersebut tidak menutup kemungkinan scrabble untuk anak usia dini dapat dibuat sendiri oleh guru yang disesuaikan dengan tema di sekolah dan bahasa yang digunakan dengan berpedoman pada scrabble junior yang telah ada. Langkah-langkah permainannya juga akan berbeda yang dilakukan meliputi : (1) bentuk persiapan berupa peralatan bermain dan media sebagai variasi permainan seperti laptop dan speaker (2) aturan permainan dibuat oleh guru untuk anak bermain dengan cara melakukannya secara bergantian dalam mencocokkan gambar dan huruf yang ada papan scrabble (3) penutupan yang dilakukan oleh guru dengan bertanya kepada anak dari kegiatan yang dilakukannya, membetulkan susunan huruf jika terjadi kesalahan agar anak tidak keliru saat melihatnya, pemberian reward di akhir kegiatan jika setiap pertanyaan di jawab dengan benar oleh anak (4) variasi permainan dengan adanya video, rekaman suara, musik dan reward dapat menimbulkan semangat anak saat bermain agar tujuan yang ingin dicapai sesuai dengan harapan.

Scrabble untuk anak usia dini dapat dibuat sendiri oleh guru dengan penyesuaian tema pembelajaran. Hal tersebut harus disesuaikan dengan syarat-syarat pembuatannya. Hal ini sesuai pendapat Rolina (2012) menyebutkan permainan anak harus memenuhi syarat berupa : (1) Memiliki nilai edukatif (2) Teknis permainan dan (3) Estetika permainan. Selain meningkatkan 
penguasaan kosakata, banyak manfaat yang didapatkan dalam penggunaan permainan scrabble terutama untuk anak usia dini. Menurut Hinebaugh dalam Sa'adah dan Nurul (2013) mengemukakan beberapa manfaat dalam permainan scrabble sebagai salah satu jenis permainan papan edukasi, yaitu: (1) Mampu meningkatkan kemampuan membaca pada anak, (2) Dapat mengembangkan perbendaharaan kosakata anak, (3) Dapat mengembangkan kemampuan dalam tata bahasa anak, (4) Mampu melatih kemampuan anak dalam mengeja suku kata, (5) Mampu melatih kemampuan anak dalam mengenal huruf-huruf dan angka.

\section{METODE PENELITIAN}

\subsection{Jenis Penelitian}

Jenis penelitian yang digunakan adalah penelitian tindakan kelas. Penelitian tindakan kelas merupakan suatu kegiatan yang sengaja dilakukan dalam kurun waktu tertentu di dalam kelas pada proses pembelajaran oleh guru atau orang yang berkepentingan untuk proses pemecahan masalah, melalui bentuk investigasi yang bersifat reflektif pertisipatif, kolaboratif dan spiral agar dapat mencapai tujuan tertentu.

\subsection{Subjek Penelitian}

Penelitian ini dilakukan dengan subjek penelitian anak di TK Dharma Wanita Mendalo Darat Kelompok B Usia 5-6 Tahun yang berjumlah 15 orang anak. Terdiri dari 7 orang anak laki-laki dan 8 orang anak perempuan.

\subsection{Alat dan Teknik Pengumpulan Data}

Adapun alat dan teknik pengumpulan data yang penulis gunakan dalam penelitian ini adalah sebagai berikut: 1). Observasi. 2). Dokumentasi

\subsection{Analisis data}

Sesuai karakteristik penilaian tindakan kelas ini menggunakan indikator keberhasilan sebagai dasar bahwa penelitian yang dilakukan berhasil atau tidak berhasil menurut Rukajat (2018:72) seperti dibawah ini :

$$
\mathrm{P}=\overline{\mathrm{n}} \mathrm{f} \times 100 \%
$$

Keterangan

$\mathrm{P}=$ Hasil persentase

$\mathrm{f}=$ Jumlah skor siswa

$\mathrm{n}=$ Jumlah keseluruhan siswa atau jumlah frekuensi

$100=$ Bilangan tetap

Kemudian dikonversikan pada skala nilai dengan rentang seratus untuk menilai keseralasan kegiatan yang dilakukan penulis. Konversi tersebut menurut Jakni (2017:82) dapat dilihat pada tabel berikut: 
Tabel 1 Konversi Nilai

\begin{tabular}{ll}
\hline INTERVAL NILAI & MAKNA \\
\hline $80,00-100,00$ & SANGAT SETUJU (SS) \\
$70,00-79,99$ & SETUJU (S) \\
$60,00-69,99$ & CUKUP SETUJU (CS) \\
$50,00-59,99$ & TIDAK SETUJU (TS) \\
$<50,00$ & SANGAT TIDAK SETUJU (STS) \\
\hline
\end{tabular}

\section{TEMUAN DAN PEMBAHASAN}

\subsection{Siklus I}

Pelaksanaan penelitian tindakan kelas terdiri atas empat kali pertemuan, yang mana pertemuan pertama memperoleh skor 40,47, pertemuan kedua memperoleh skor 48,33, pertemuan ketiga memperoleh skor 63,85, pertemuan keempat memperoleh skor 72,19. Secara lebih rinci dapat diperhatikan pada gambar sebagai berikut:

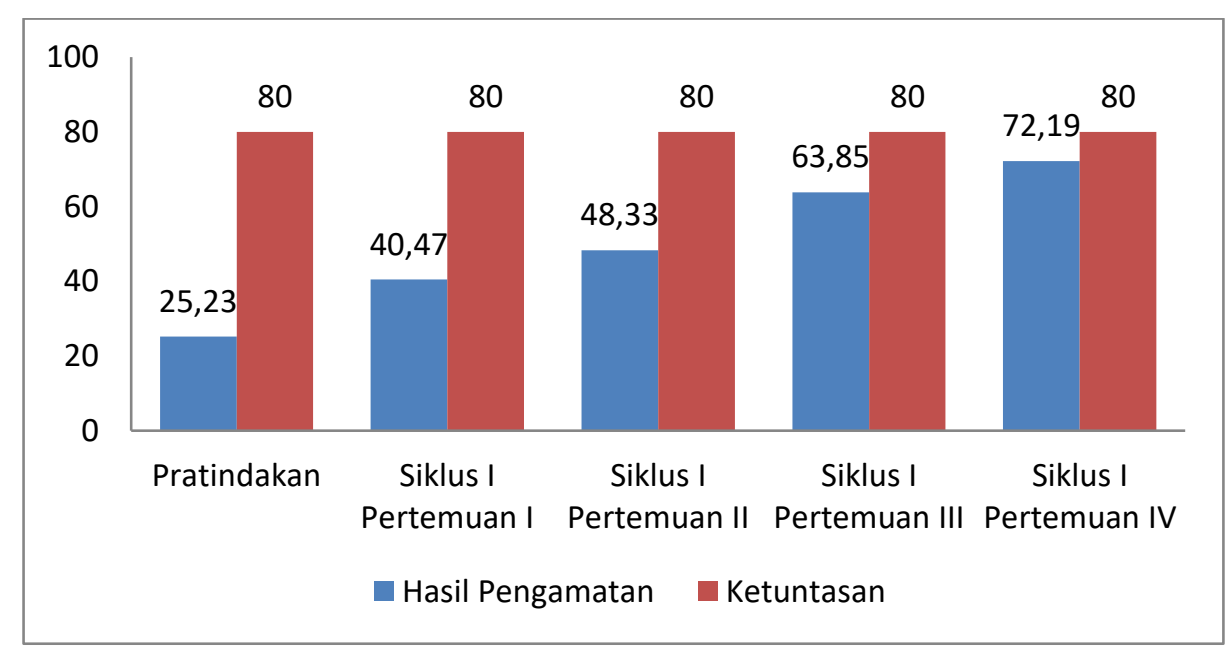

Gambar 1. Grafik perbandingan pratindakan dan siklus I

Hasil PTK pada siklus I pertemuan IV belum maksimal dengan 72,19\% termasuk pada kategori setuju dan tidak sesuai dengan kriteria ketuntasan. Oleh karena itu, penulis dan guru secara bersama-sama merencanakan kegiatan pada siklus II pertemuan I.

\subsection{Siklus II}

Perolehan hasil siklus II, dengan perbandingan setiap pertemuan, digambarkan dalam bentuk grafik sebagai berikut :

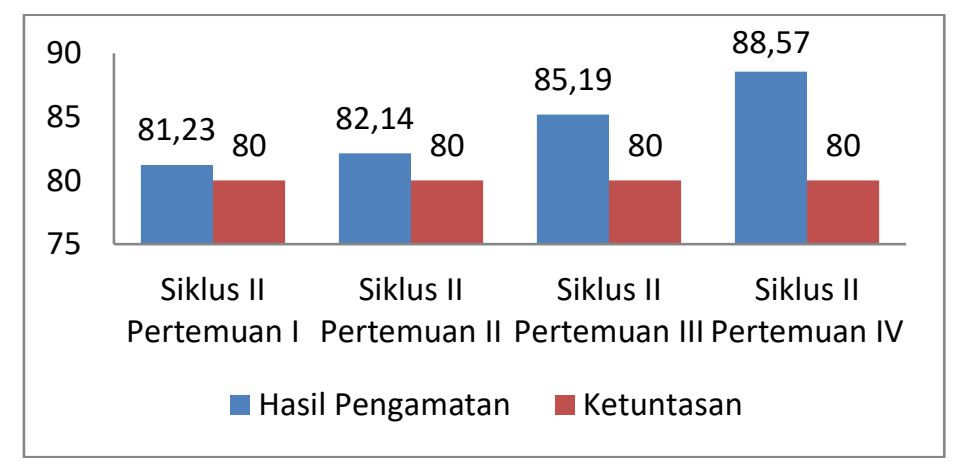

Gambar 2. Grafik hasil pengamatan siklus II 
Berdasarkan grafik perbandingan tersebut, dapat dipahami bahwa penelitian pada siklus I dan siklus II tentang penguasaan kosakata anak di TK Dharma Wanita Mendalo Darat sudah mencapai kriteria ketuntasan. Pada siklus II penguasaan kosakata anak usia 5-6 tahun berkembanag sangat baik dengan kategori sangat setuju sesuai indikator yang telah ditentukan. Hal ini terlihat dari presentase siklus $72,19 \%$ menjadi $88,57 \%$ sesuai dengan kriteria ketuntasan. Setelah hasil siklus II sesuai dengan kriteria penelitian, maka penelitian dihentikan.

Hasil penelitian yang telah dilakukan untuk meningkatkan penguasaan kosakata anak melalui permainan scrabble dapat dikatakan berhasil dilihat dari penilaian yang telah dilakukan sesuai indikator yang harus dicapai pada penguasaan kosakata. Selain itu anak terlihat mengalami perubahan secara bertahap dari hasil presentase yang didapatkan dari masing-masing pertemuan pada setiap siklus. Hal ini sesuai dengan penelitian yang Hardianti (2019) tentang Pengembangan Alat Permainan Edukatif Scrabble untuk Meningkatkan Kemampuan Membaca Permulaan Anak Kelompok B".

Selain itu, penguasaan kosakata yang mampu dipahami oleh anak yaitu berupa kata benda, kata kerja, kata sifat, serta beberapa kelas kata bahasa indonesia. Pada penelitian yang telah dilakukan penulis, kata-kata tersebut sudah mampu dilakukan anak dengan baik melalui tindakan yang diberikan. Hal ini sesuai dengan penelitian Markus, Kusmiyati, dan Sucipto (2017), bahwa anak sudah menguasai hampir semua kelas kata bahasa Indonesia. Mulai dari kata nomina, verba adjektiva, adverbia, pronomina, numeralia, preposisi, konjungsi, sampai dengan interjeksi.

Permainan scrabble banyak sekali manfaat yang akan didapatkan oleh anak, selain meningkatnya penguasaan kosakata dan kemampuan membaca permulaan pada anak ada juga kemampuan menulis anak dapat ditingkatkan melalui permainan scrabble. Hal ini sesuai dengan penelitian yang dilakukan oleh Puranik dan Christopher (2011) yang berjudul From Scribbles to Scrabble: Preschool Children's Developing Knowledge of Written Language (Dari Scribbles ke Scrabble: Mengembangkan Pengetahuan Anak-Anak Prasekolah tentang Bahasa Tertulis)". Hasil penelitian ini menunjukkan bahwa permainan scrabble dapat mengembangkan kemampuan menulis anak dari kata dan komponen huruf yang dilihat kemudian diaplikasikan dengan cara menulis yang dilakukan oleh anak.

Penguasaan kosakata anak dapat ditingkatkan melalui berbagai kegiatan bermain anak. Salah satunya melalui permainan scrabble yang berisi tentang rangkaian kata yang disusun oleh komponen huruf-huruf yang mudah dipahami anak. Selain permainan tersebut permainan lain juga dapat meningkatkan penguasaan kosakata anak seperti permainan ular tangga sesuai dengan penelitian yang dilakukan oleh Sudarmanto, Pamungkas, dan Anggraini (2012) yang meneliti tentang Peningkatan Kosakata Benda Melalui Permainan Ular Tangga pada Kelompok B di TK Pertiwi Tamanagung Muntilan". Hasil Penelitian ini menunjukkan bahwa kosakata dapat ditingkatkan melalui permainan ular tangga yang disesuaikan dengan tema dengan penggunaan modifikasi ular tangga.

Selain itu penelitian Hidayati (2017), dalam Meningkatkan Kosakata Bahasa Inggris Anak Usia Dini dengan Kartu Bergambar (Flascard) di TK Terpadu An-Nisa' Tuban”. Hasil penelitian melalui penggunaan flascard anak terlihat semakin bersemangat dalam melakukan kegiatan dari melihat gambar yang lucu dan berwarna yang ada pada kartu. Anak-anak terlihat aktif dalam bermain sehingga penguasaan kosakatanya meningkat dari setiap siklus. Melalui perbandingan penelitian tersebut menunjukkan bahwa penguasaan kosakata anak dapat mengalami peningkatan dengan penggunaan media permainan yang menarik sehingga mampu menarik minat anak untuk bermain dengan baik sehingga tujuan dapat tercapai sesuai harapan. 


\section{KESIMPULAN DAN SARAN}

\subsection{Kesimpulan}

Berdasarkan hasil dan pembahasan, maka dapat disimpulkan bahwa penguasaan kosakata anak usia 5-6 tahun dapat ditingkatkan melalui permainan scrabble di TK Dharma Wanita Mendalo Darat. Tindakan yang digunakan sesuai dengan usia dan kemampuan anak dalam menyusun komponen huruf dan menyebutkannya. Permainan dimodifikasi sesuai dengan tema pembelajaran anak yang menarik dan bervariasi di setiap pertemuan. Selain itu, pada siklus II ditambahkan penggunaan media pendukung berupa iringan musik rekaman suara sesuai dengan kata pada scrabble dan diberikan reward. Anak terlihat semakin senang dan bersemangat dalam bermain sehingga berebutan saat menyusun dan menjawab pertanyaan dari guru.

Melalui pengamatan penguasaan kosakata anak usia 5-6 tahun dari hasil pratindakan dapat diperoleh hasil penelitian yang dilakukan sebelum dan sesudah adanya tindakan siklus I dan siklus II sebagai berikut :

1) Sebelum adanya tindakan yang diberikan penguasaan kosakata anak usia 5-6 tahun masih belum berkembang sesuai harapan pada indikator ketuntasan dengan presentase $25,23 \%$.

2) Setelah dilakukan tindakan pada siklus I yang terdiri dari IV pertemuan mulai menunjukkan kemajuan secara bertahap yang dihasilkan oleh anak dilihat dari presentase setiap pertemuan. Adapun hasilnya meliputi pertemuan I 40,47\%, pertemuan II 48,33\%, pertemuan III 63,85\%, peretmuan IV 72,19\%.

3) Setelah dilakukan tindakan pada siklus I belum mencapai batas ketuntasan yang telah ditentukan, sehingga diperlukan kelanjutan siklus II untuk memperoleh hasil yang sesuai dengan ketentuan. Pada siklus II ditambahkan media tambahan berupa rekaman suara dengan iringan musik sebagai penunjang proses bermain anak sehingga menghasilkan data dengan presentase yang meningkat sesuai harapan. Adapun hasilnya pertemuan I 81,23\%, pertemuan II 82,14, pertemuan III 85,19\%, dan pertemuan IV 88,57\%. Dari hasil di atas menunjukkan penguasaan kosakata anak usia 5-6 tahun melalui permainan scrabble mengalami peningkatan yang signifikan melebihi batas ketuntasan yang telah ditentukan yaitu $80 \%$ dengan hasil yang didapatkan $88,57 \%$.

\subsection{Saran}

Berdasarkan kesimpulan yang ada, maka penulis memberikan saran sebagai berikut :

1) Bagi Sekolah

2) Melalui adanya permainan scrabble yang digunakan sebagai permainan anak, maka dapat memotivasi sekolah agar dapat memenuhi kebutuhan alat permainan edukatif agar menunjang proses pembelajaran anak.

3) Bagi guru

4) Melalui permainan scrabble, guru dapat mengembangkan strategi dalam proses pembelajaran yang kreatif, menarik dan menyenangkan bagi anak untuk mengasah kemampuan anak dalam penguasaan kosakata anak usia 5-6 tahun.

5) Bagi Anak

6) Melalui permainan scrabble anak lebih termotivasi dan bersemangat pada kegiatan bermain sambil belajar dalam meningkatkan penguasaan kosakata anak sesuai kemampuan yang dimilikinya.

7) Bagi Penulis Selanjutnya 
8) Penulis diharapkan dapat menjadi lebih kreatif dalam pelaksanaan kegiatan yang disertai dengan penggunaan media permainan untuk mencapai tingkat keberhasilan penelitian yang lebih maksimal. Selain itu, semoga hasil penelitian ini dapat menjadi motivasi bagi penulis berikutnya untuk melakukan penelitian lebih lanjut.

\section{DAFTAR PUSTAKA}

Alawiyah,dkk. 2018. Pengaruh metode bercerita dongeng sikancil terhadap penguasaan kosakata pada anak kelompok b di RA Az-Zahro Kecamatan Mranggen Kabupaten Demak Tahun 2018/2019. Jurnal Penelitian Dalam Bidang Pendidikan Anak Usia Dini. No 2, Vol 7. ISSN 2089-1431 (Print), Issn 2598-4047 (Online). http://dx.doi.org/10.26877/paudia.v7i2.3265.

Djiwandono, Soenardi. 2011. Tes Bahasa Pegangan Bagi Pengajar Bahasa. Jakarta: Indeks.

Hardianti, Farlina. 2019. Alat permainan edukatif scrabble untuk meningkatkan kemampuan membaca permulaan anak kelompok b. Jurnal Golden Age. Vol. 3 No. 01. E-ISSN : 2549-7367. http://dx.doi.org/10.29408/goldenage.v3i01.1354

Hidayati, Niswatin N. 2017. Meningkatkan kosakata bahasa inggris anak usia dini dengan kartu bergambar. Jurnal Al Hikmah: Indonesian Journal Of Early Childhood Islamic Education. ISSN: 2550-1100, VOL. 1 (1), 2017, PP. 67-86. http://journal.staialhikmahtuban.ac.id/index.php/ijecie/article/download/6/7/

Jakni. 2017. Penelitian Tindakan Kelas (PTK). Bandung: Alfabeta.

Markus, dkk. 2017. Penguasaan Kosakata Bahasa Indonesia Anak Usia 4-5 Tahun. Jurnal Fonema. Vol 4 No. 2. ISSN 2087-9253 (cetak). ISSN 2597-9795 (online). http://ejournal.unitomo.ac.id/index.php/pbs

Puranik dan Cristopher. 2011. From Scribbles to Scrabble: Preschool Children's Developing Knowledge of Written Language. NIH Public Acces. Vol 24 No. 5. DOI: $10.1007 / \mathrm{s} 11145-009-9220-8$.

Rolina. Nelva. 2012. Alat Permainan Edukatif Untuk Anak Usia Dini. Yogyakarta: Ombak.

Rukajat, Ajat. 2018. Penelitian Tindakan Kelas. Yogyakarta: Budi Utama.

Sa'adah dan Nurul. 2013. Pengaruh permainan scrabble terhadap peningkatan kemampuan membaca anak disleksia. Jurnal Fakultas Psikologi. Vol. 1, No 1. ISSN : 2303-114. http://journal.uad.ac.id/index.php/EMPATHY/article/view/3000

Sofyan, Hendra. 2015. Perkembangan Anak Usia Dini Dan Cara Praktis Peningkatannya. Jakarta: Infomedika.

Sofyan, dkk. 2019. Development of e-modules based on local wisdom in central learning model at kindergartens in jambi city. European Journal of Educational Research. Vol 8. No.4 Hal 1137-1143. ISSN : 2165-8714. http://www.eu-jer.com/ 
Sudarmanto,dkk. 2012. Peningkatan kosakata benda melalui permainan ular tangga pada kelompok b di tk pertiwi tamananggung muntilan. Jurnal Pendidikan Anak. Vol.1. No.2. https://doi.org/10.21831/jpa.v1i2.3023

Sujiono, Yuliani. 2013. Konsep Dasar Pendidikan Anak Usia Dini. Jakarta: Indeks.

Tarigan, Henry. 2015. Pengajaran Kosakata. Bandung: Angkasa.

Yusuf, S dan Nani M. S. (2012). Perkembangan Peserta Didik. Jakarta: Raja Grafindo. 